\title{
4
}

\section{Re-dressing Materiality: Robes Mission from 'Colonial' to 'Cultural' Object, and Entrepreneurship of Kanak Women in Lifou}

\author{
Anna Paini
}

'Colored textiles for Terra Madre' read the caption of a photograph of a Kanak woman from Lifou wearing a robe mission (mission dress) at the opening ceremony of Terra Madre 2008; ${ }^{1}$ I had not expected that the Kanak delegation present at this international bi-annual event organised by Slow Food in Turin, where for the first time natural fibre producers were invited, would attract such interest and be one of the most photographed. Even women from Central Asian countries dressed in clothes made with precious, finely ornamented hand-woven fabrics wanted to be photographed with Kanak women, who wore robes mission tailored from an industrial printed cotton fabric with floral motifs, white on a red background. The choice of fabric (colour and floral motifs) was made by a member of the delegation. I later realised that it was the colour code of the village in Lifou, Loyalty Islands, where the woman and her husband (a pastor of the Evangelical Church) were living at the time.

1 See Terra Madre Salone del Gusto website 2008. The picture accompanying an article on natural fibres appeared in the supplement devoted to the event in the daily newspaper la Repubblica (Torino), October 24 2008: v. 
One of the people eager to be photographed with the Kanak wanted to be reassured that it was their 'traditional costume'; her question brought home to me the reason beneath this fascination for the robe mission. It was perceived by other participants as the Kanak costume, a dress that is standardised not only in form but also in colours and motifs, and thus the red and white fabric with floral motifs was perceived as a conventional element of the traditional Kanak dress, rather than a choice related to the occasion.

I start from this vignette to look into the complex semantic and symbolic dimensions of the robe mission, an article of clothing of colonial origin worn by Kanak women in Lifou, and more generally in Kanaky New Caledonia. It is an introduced garment, which has been appropriated by Kanak women and incorporated into their customary and daily life as a versatile outfit: worn on important and formal occasions, its life continues as a garment for working in the fields and then, once old, crumpled and torn, finishes its life as a useful rag. In time its materiality, meanings and values have been transformed. As Igor Kopytoff has argued 'what is significant about the adoption of alien objects - as of alien ideas-is not the fact that they are adopted, but the way they are culturally redefined and put to use' (1986: 67). And as Nicholas Thomas has remarked concerning the introduction of clothing by missionaries in this part of the world, 'it is most evident that these garments have not been inflicted, but adopted by entirely dignified women' (2005: ix).

The dress of very light cotton gauze, which today reaches below the calf, in the 1980s and 1990s could be worn buttoned at the front or at the back. ${ }^{2}$ The versatility of this article of clothing is such that it has also been adopted by cricket players. In this, the leading women's national sport, each team is identified by the colour code of its uniform. The styles vary from season to season with new colours, new fabrics and new patterns. In the twenty-first century the changes have been faster and even more innovative, concerning both the style of the dress-which has gone through changes in the fabrics, colours and motifs, and the design of certain parts of the dress such as the carré (yoke) and the sleeves-and its manufacturing, today often in the hands of Kanak women tailors. A flourishing entrepreneurship centred on the robe mission is growing.

2 The more recent models of robe mission do not have buttons. 
Female sartorial entrepreneurship is unprecedented for Lifou, as in the past the production of the robe was the monopoly of Chinese tailoring workshops in Nouméa, the capital.

The mission dress is thus quite distant from the image of the monotonous garment and never-changing style which looms so large in the early writings from Lifou as well as in the rhetoric of researchers up to the 1990s, who have never shown interest in a garment that they assumed to be imposed by European colonial rules. I present a more articulated story, a story from the perspective of Lifouan women and a telling case of 'tides of innovation'. The robe mission is one of those exogenous elements that have been indigenised, showing local capacity to appropriate what comes from other contexts and at the same time that a variety of elements coalesced in the process of indigenisation (see Paini 2012). I consider this as a privileged arena for illustrating how agency is retained with local actors - women in particular.

Vilsoni Hereniko comments that 'the profound sense of belonging ... is lost when what we wear ceremonially is not woven collectively with the blood, sweat and tears of our elders, but by cotton thread and needle pushed along by foreign machines' (2005: 108). This vision needs to be tweaked a little in order to fit the story of Kanak women and their robe mission, a story in which materiality-value-place are differently connected; a story and a vision which provide the focus for this article.

I looked into the complex and articulated story of this dress, a garment that has caught my attention since my doctoral fieldwork and which later became the subject matter of my research (Paini 2002, 2003a, 2009, 2012). My discussion of the robe mission as a multidimensional subject matter is based on data from my fieldwork and on archival material in order to show how the transition from colonial to cultural object was activated by Kanak women and stresses women's dynamism and protagonism in the setting in motion of these changes. Men until very recently have been less interested in the topic, and non-governmental organisations (NGOs), which are very seldom present in the country, have played no role.

A brief foray into the question of Kanak women's appraisal of a loose garment different from the robe as the uniform to wear on a couple of official occasions gives weight to my argument (see Paini 2003a). The episodes were recounted by a Kanak male interlocutor involved in both events. The choice of the uniform of women working in the 
Jean-Marie Tjibaou Cultural Center in Nouméa (which opened in 1999) was not an easy one. The proposal of a different style of loose garment was debated during the working committee, and whereas men favoured the change, women preferred the robe mission. For the Festival of Pacific Arts held in Nouméa in 2000, the choice of a loose garment, designed by two young female stylists, as the uniform of the personnel escorting the guest delegations was contested by several Kanak women. The same male interlocutor from the Grande Terre (main island) favourably commented on this choice: 'It was the only time in which the mission dress was avoided', adding that 'it was important to break the habit of using the mission dress because it is the symbol of the church' (Boengkih, 23 August 2001). ${ }^{3}$ This echoed the more ambiguous connotations associated with the mission dress in those years in some other parts of Melanesia. ${ }^{4}$ Since then many works on cloth and clothing have taken another perspective, more articulated, well put forward in a recent article by Margaret Jolly: 'They were and are fabrics saturated with the values of indigenous sanctity and rank, anti-colonial resistance, cultural pride, women's collectivities, national identities and transnational connections in an increasingly globalised world'(2014: 433).

Nevertheless, I consider it is important to remember how the robe has been differently reclaimed in Lifou and in the Grande Terre through time and how this echoes different configurations of colonial history (among others, see Bensa and Leblic 2000; Bensa, Goromoedo, Muckle, 2015 (including a very detailed bibliography); Douglas 1998; Merle 2002; Shineberg 1999; Tijbaou 1996). Recall that Lifou unlike the main island was not converted into a penal colony in the second half of the nineteenth century nor invested by land alientation and the program of free colonisation through the policy of cantonnement, which confined Kanak to the reserves (see Paini 2007, forthcoming in French). ${ }^{5}$

3 References to interviews are followed by name of the interlocutor and date only when the information refers to one single interview; otherwise only the name of the interlocutor is given.

4 For instance, the artist Ellen José from the Torres Strait Islands regarded the mission dress as a strong symbol of colonial and religious intervention on Islander women's lives, and this became the conceptual frame for one of her art works in which lifeless black mannequins were shown wearing a mission dress (Jolly 2001, 2003). This contrasted with the work of Kanak artist Denise Tiavouane as revealed in her exhibition at the Jean-Marie Tjibaou Cultural Center in Nouméa in July 2001 (Mwà Véé: 2001; see also Paini 2003a).

5 On forms of control over indigenous mobility by colonial authorities as well as freed convicts and indentured labourers in New Caledonia, see Muckle 2011. He also points out the 'preoccupation with controlling the movement of Kanak women' and 'the regulation of movement between the Loyalty Islands and Nouméa' (148). 
Following Kopytoff's argument that 'biographies of things can make salient what might otherwise remain obscure' (1986: 67), this chapter is deliberately ethnographic in its emphasis in order to convey the multidimensional features condensed in the Kanak robe mission (see also Paini 2003a).

\section{A versatile exogenous garment: An acceptable ethnographic subject?}

Unlike other areas of the world, the literature on the Pacific region has marginalised the role of cloth and clothing in colonial and missionary history until the early 2000s. ${ }^{6}$ As pointed out by Chloë Colchester (2003), although it has been recognised as a key area of intervention, particularly by the missionaries, only in the twenty-first century has research on cloth, clothing and the manufacture of dresses produced a number of publications, opening up a new and interesting field and making clothing an ethnographic subject that is 'good to think with'.

Clothing has been an area of relative little interest in ethnographic and historical studies on New Caledonia. The only publication of the past on the subject, to my knowledge, goes back to 1953. That year's monographic issue of Journal de la Société des Océanistes, dedicated to New Caledonia, presents an overview of the subject by Patrick O'Reilly and Jean Poirier. In 'L'évolution du costume', the two authors stressed that although prohibition of nudity was a joint objective of the agents of colonisation, government and missions, the French administration was more interested in dressing chiefs in gallooned uniforms. It was mainly the discourse of white missionaries that focused on the imposition of a conjugal moral, the valorisation of the domestic milieu $^{7}$ resulting in the imposition of moral restraint on bodies that so far were dressed according to local customs and now had to conform to western norms of decency. Although for most missionaries nudity had been emblematic of savagery, O'Reilly and Poirier argued that it was forbidden by pre-European indigenous morality, which imposed a strong sense of modesty, though regarding only the pubic area. Maurice Leenhardt (1978: 4) reflected on

6 But see Weiner (1989).

7 On Christian missionaries' intervention in Pacific women's daily life, see Douglas 2002, 2003; Jolly and Macintyre 1989; Jolly 1991; also Jolly 2012 and 2014, including a very extensive bibliography. 
the 'false modesty' of western society, which is alien to many non-western peoples, as they 'distinguish the idea of nudity from that of decency. The misfortune of our culture has been that of mixing the two ideas, and to hold nudity, even that of a child, as indecent' (4). Further, Leenhardt's article, which was first published in 1932, stressed the importance for these populations of wearing ornaments because wearing them means 'being invested with the power they contain' (4).

As I have discussed in a previous essay (Paini 2003a), my older Lifouan female interlocutors in the 1990s acknowledged that the sense of modesty and shame vis-à-vis their body was recent, a post-European contact development. They also recalled that in the past women were bare breasted (see also Tcherkézoff 2003) and that female modesty required covering the pubic area. During my doctoral fieldwork, women breastfed in public and some of the older women at home still wore only a skirt (this was reported to me by some Protestant women referring to their elder relatives). Also, the advice given to me by local women in the first months of my fieldwork in 1989 as to how to wear a robe mission properly always concerned this part of the body. Women have developed bodily techniques which allow them to crouch or to sit with crossed legs taking advantage of the fullness of the dress, which is tucked in between the legs, an 'investment of existing indigenous preoccupations into new materials' (Küchler and Were 2005: xxi). Coming from a Catholic background, where girls were taught to keep their knees covered, I was intrigued by this indigenous solution in which thighs were not concealed. For Lifouan women it is simply a natural and comfortable style of sitting, though I have always found it awkward to adopt myself. Roberta Colombo Dougoud, writing about her fieldwork experience in Papua New Guinea, recounts a similar story (2002: 56) —women persisted in telling her how to sit properly, by folding the skirt between her legs.

The robe mission is not to be considered as a costume but rather as an item of clothing, although it has become included in customary exchanges (I'll return to this). Thus the dimensions of ordinariness, of creolisation, its colonial origin and its name meant that for a long time it was a very visible yet ambiguous object: although the windows of the shops in the Chinese quarter were filled with colourful mission dresses, they were invisible to researchers in the late 1980 s and early 1990s. A dress too entangled with colonisation and considered only as an introduced garment inflicted on Kanak women, could not be taken into account by an ethnographic research which positioned itself as committed. Instead, I suspect that the idea that clothing was an irrelevant aspect of daily life was upheld 
by the binary logic of authenticity and inauthenticity, and thus the robe mission - perceived as an unauthentic, spurious, contaminated objectwas not considered a proper ethnographic subject matter.

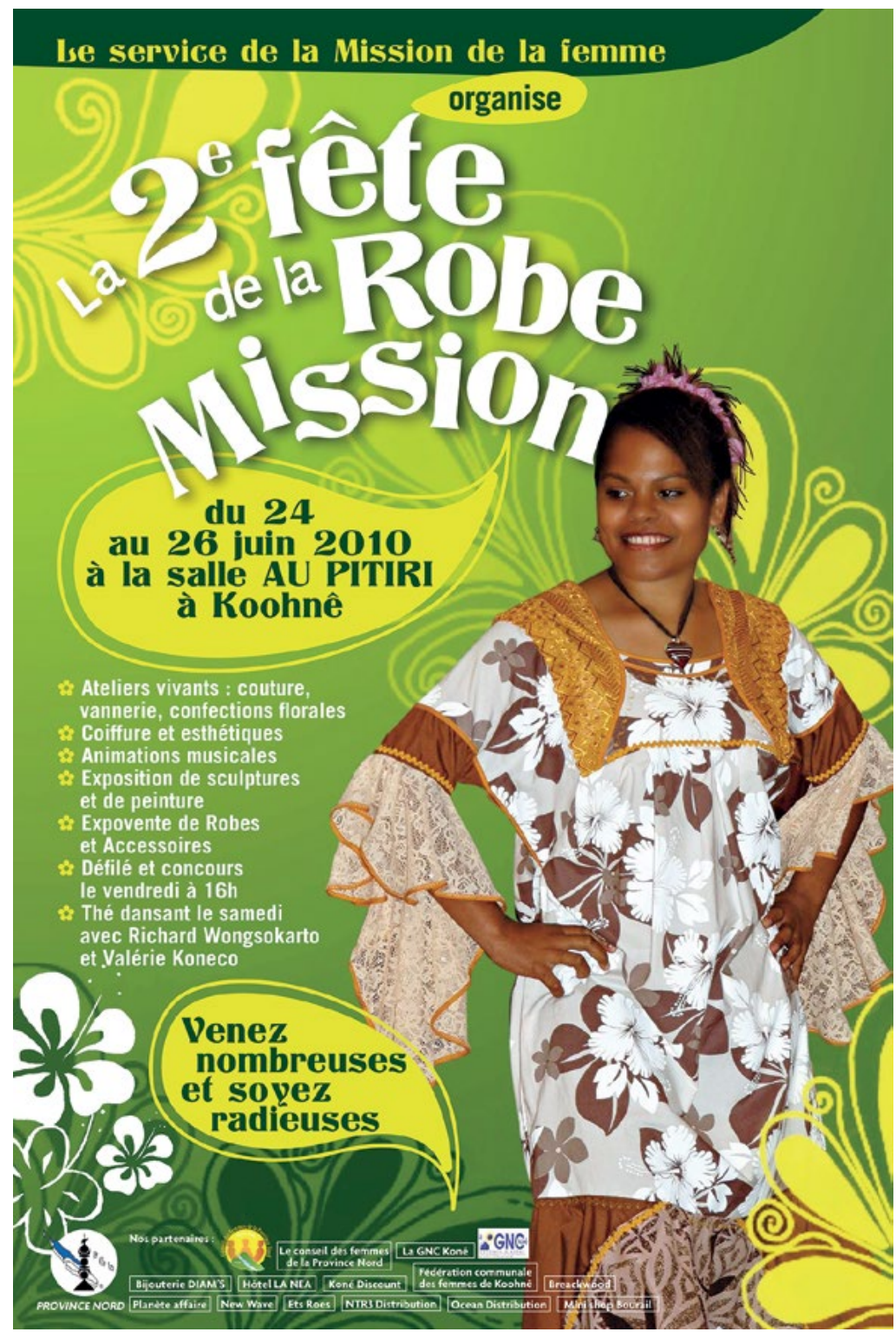

Figure 19. Poster of the second Fête de la Robe Mission, June 2010, Koohné

Source. Provided by the organisers 
From a certain visual angle what works for other objects also applies to the robe. 'Commonplace things are worn to oblivion and replaced with new objects, or are viewed as too trivial in their own time to be removed from circulation ... and saved for posterity' (Kirshenblatt-Gimblett 1998: 25). Indeed the robes mission are seldom preserved for posterity because as they grow older and worn they are used for working in the gardens, and finally they become household rugs or rags. This can explain why robes mission, until recently, were absent from museum collections.

However, the first years of the twenty-first century have seen a new wider interest in the subject, as revealed by some events organised in Nouméa: from the 2000 Festival des Arts du Pacifique (23 October-3 November) where a section was devoted to clothing, to a photographic exhibition on the robe mission in 2003 at the Jean-Marie Tjibaou Cultural Center (20 August-3 November). More recently, an issue of Mwà Vée (2010), the journal of the Cultural Centre, was entirely devoted to the mission dress. It featured several interviews, an account of the second Fête de la Robe Mission (Figure 19) and images and conversations with the artists who were involved in the exposition of contemporary art Robes mission: un art de la rue? which opened in June 2010 at the Cultural Center in Nouméa. The mission dress has at last been recognised as an artistic and ethnographic subject. ${ }^{8}$

\section{A nyipi dress 9}

Following local usages which draws a rigid distinction between fille and femme (married and unmarried women) regardless of age (see Paini 2007), for this essay I draw mainly from the experiences and insights I shared throughout the years with married women. Let's take a closer look at this robe, starting with the 'three buttons model', which had been the mainstream model up to the end of the 1990s. I deliberately present a detailed description of it as this allows me to draw comparisons with later models and describe the innovations that occurred over time. A tulu, or yoke, is shaped and fitted around the neck, it is decorated in the front with lace or cotton braids, and has three buttons at the back. The rest of the garment is gathered and hangs loosely from it, with no indication

8 I do not explore here the use of the robe mission in the work of artists such as Stéphanie Wamytan. It is the focus of a forthcoming essay.

9 Literally, true/dress. 
of a waistline. The neck- hninawa-is emphasised by a high neckline, the opening reaches the mid-back and closes with three buttons, usually white or clear, with two holes and sewn almost indifferently on the right or the left side, contrary to western custom which differentiates closure according to gender. The sleeves_imen (à la raglan)—are very wide and stop above the elbow. They have a border accentuated with bands of lace or ribbons matching the yoke, slightly gathered by a string on the inside to create a ruffle.

Younger women ignore the elements that in the past distinguished a Lifouan robe from one worn by a woman from the nearby island of Ouvéa. As Pohnimë Haluatr told me repeatedly over the years, in the first case three galons, or lace, delimited the yoke, in the second only two. I want to draw attention to this detail because it shows that women were able to invest local meanings in the robe by replicating in the acquired dresses elements that were present in other forms in their pre-European clothing. And this contradicts what is often argued: that the new imported clothes had replaced the local ones suppressing any difference in origin and status.

Isabelle Leblic, in an essay on technical changes in the fishery sector since the introduction of objects from outside, insisted that the substitutions made by the Kanak concern 'functionally equivalent objects' or items that are different from the traditional ones 'for the materials of which they are made: they already exist in the system in the equivalent form' (1998: 92). However, Lissant Bolton, in her writing about the introduction of European clothing in Vanuatu takes a different position: '[they] represented not just the substitution of one material form for another, but the importation of a different set of ideas and distinctions embodied in the specific material form of introduced clothing' (2003: 126). Yet, she stresses that if the adoption of clothing was viewed by missionaries as a sign of conversion, 'the specifics of how this was imposed and received varied greatly from place to place' (2003: 127). In the case of Vanuatu, Bolton argues that the distinctions of status previously associated with indigenous clothes were lost in the 'Mother Hubbard' dress, adding that 'the principal source of differentiation marked by clothes reflected missionary denomination' (129). Women's dress among the Anglicans consisted of a blouse (today a t-shirt) and skirt, whereas Presbyterians wore a dress, often called Mother Hubbard. Bolton further comments that this term was used only to refer to indigenous women's clothing, thus creating 'a specific distinction between expatriate and indigenous' (129). I find Bolton's delineation of the shift from old to new clothing 
very inspiring. In Lifou, though, the introduction of the mission dress has not produced the same dynamics, as certain regional differences in style and status have long been incorporated into the robe. Kanak women were able to reappropriate an exogenous garment transferring some elements of distinction based on status, age, as well as the village of belonging; distinctions which, however, have weakened over the years. ${ }^{10}$

Kanak women clearly show a yearning for robes mission. When the late Hnauleqatr spoke of the robe at the time the missionaries were a constant presence in Lifouans' life, she pointed to the lack of laces in those imported garments. The material was heavier and the dress touched the feet. When women describe the robe of the more recent past they specify that it was trimmed with more lace and folds. The dresses displaying more trimming were considered nyipi ewekë la $i$ heetre popine (the dress of value for women). ${ }^{11}$ In the words of Billy Wapotro, a Kanak interlocutor, nyipi heetr referred to Sunday best. The use of the term nyipi requires some clarification. It is a very dense term that points to the linguistic process through which a non-local object acquires 'authenticity' and thus becomes indigenised, particularly for the older generations. The recent origin of the dress is concealed by a linguistic label that allows Kanak to assign it a new status (Milie and Paini 1996), which also reveals an indigenous attribution of hierarchy upon categories of clothing. A once imposed dress, the robe mission has gone through cultural reformulation not only in its materiality but also in the linguistic label attached to it. ${ }^{12}$

The quality of the material and the manufacturing varies. The fabric comes from Asia, ${ }^{13}$ mostly from Taiwan: relatively cheap, colourful, and printed mainly in bold floral designs. There is a wide choice of colours and colour combinations. The dress today covers the knee, but fashion has also affected this aspect and during the 1960s the dress was shorter. Pohnimë showed me a dress from that period, the only one that I was shown to

10 The aforementioned differences are not taken into account in the article by O'Reilly and Poirier (1953).

11 In the use of Drehu orthography I follow Dictionnaire Drehu-Français by Léonard Drïle Sam, 1995.

12 The notion of foreignness has been the focus of fieldwork carried out in 1996 with Imela Milie from Lifou thanks to an Etude des Sociétés Kanak (ESK), École des hautes études en sciences sociales (EHESS) grant. See the paper 'Ka xep qa hnagëje (everything that comes from the sea); or foreignness as articulated by Lifuans', presented by the two of us in December 1996 at the European Society for Oceanists (ESfO) conference in Copenhagen.

13 I have met a Kanak dressmaker who used to go to India to buy fabrics to stock her store. She had a few seamstresses working for her in Nouméa. 
have been preserved from earlier times: it was shorter than present-day ones, made of nylon, and in gaudy colours. Photographs from Melanesia 2000, the first festival of Kanak arts held in Nouméa in September 1975, support this (Tjibaou and Missotte 1978).

The dress can be worn buttoned at the front or at the back. Dwelling on this is not simply to get hung up on ethnographic details, rather 'such biographical details reveal a tangled mass of aesthetic, historical, and even political judgments, and of convictions and values' (Kopytoff 1986: 67). If in the 1990s on important occasions the robe was buttoned at the back, in the past the dress was worn with the three buttons at the front. The narratives on this point differ: for some women the reason was practicality, the high neckline impedes movement when the dress is buttoned at the back; for others this practice was associated with Protestant women, especially the wives of pastors, who could thus follow the service at the same time as they were breastfeeding. However, some women suggested that it was not only for practical reasons as it distinguished a status, more generally a way 'to signal the status of a married woman' (Kacatr, We, 14 August 2001). A photograph taken at a Catholic women's gathering in July 1971 and given to me by Pohnimë Haluatr, ${ }^{14}$ shows her, at the time married and with three children, with other women from Drueulu wearing the dress buttoned at the front. Yet one of them was not married (Figure 20). As undergarment, an underskirt—iut—made with cotton or synthetic material replaces that of the past made of thick and colourful fabric, laced at the waist. Women also used to wear a large camisole, isimis; after giving birth they also used a hidden belt to support the stomach. Some elderly women still use isimis and iut and they are still included in the customary gift made to the bride's family. There is also a standard way to store this garment. The locally appropriate way requires a woman to fold the dress vertically in half, then to fold in both sleeves and finally to fold it into thirds starting from the bottom and ending with the yoke on top.

14 The photograph was in bad condition, I took it back to The Australian National University, had a new negative and new copies made, and later I returned the original and a new copy of the photo to its owner. 


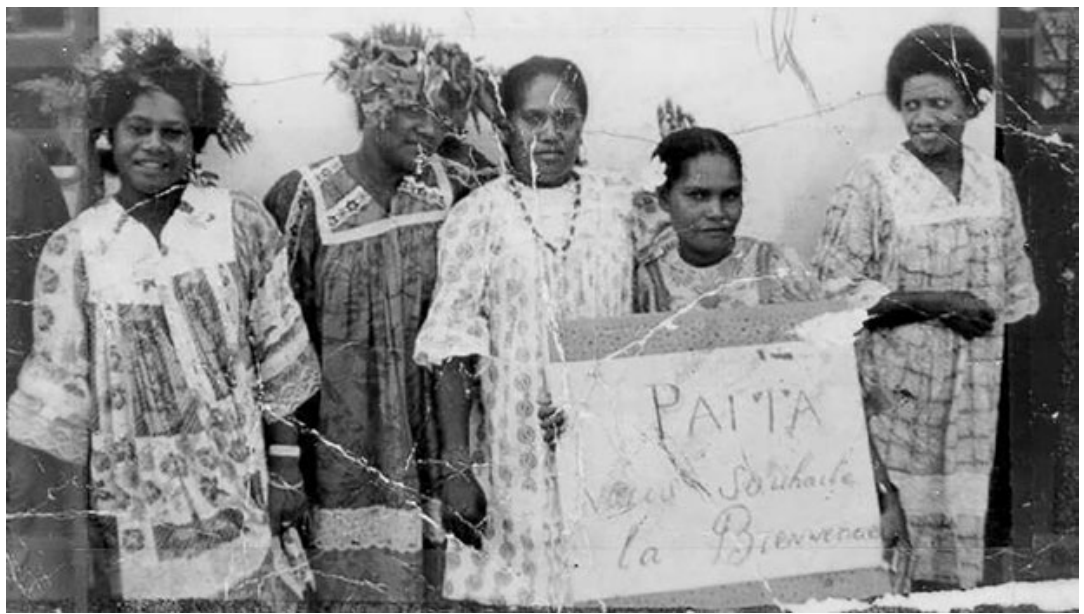

Figure 20. Pohnimë Haluatr (far left) and other Loyalty Islander women in Paita, near Nouméa, July 1971

Source. Photograph courtesy of Pohnimë Haluatr, Drueulu (Lifou)

Juxtaposing oral and written sources as I have attempted to do in my research on the robe mission (Paini 2003a, 2009), I am not aiming to reconstruct the history of this dress, but rather to evince the selective use of memories and the narratives deployed that reveal similarities and differences both between Catholics and Protestants and between the Grande Terre (main island) and the Loyalty Islands. Indeed, the distinction between Lifouans belonging to the two missions established on the island since the mid-1850s has always been strongly marked and visible (see Paini 1998). In the period between 1930 and 1950 Catholic Fathers imposed both dress and hairstyle 'norms' on church-going women to mark them apart from Protestant women. Nevertheless, it was mainly the hairstyle that expressed difference: Catholic women wore their hair short, reintroducing a local pre-European practice. During my fieldwork in the late 1980s to the early 1990s, while women expressed no regret concerning the differences in clothing, they harboured a deep grudge against the hairstyle rule imposed by a specific missionary.

The fact that both Catholic and Protestant women's narratives account for religious differences through the memories of the imposition of a different hairstyle and not of a different practice of clothing means that today the robe mission is perceived as the proper dress by Kanak women, regardless of their religious affiliation, quite a different situation from that analysed by Bolton in Vanuatu, where Presbyterian women 'see the dress as particularly 
their own' (2003: 134), whereas Anglican women do not. I'll return to this. Paradoxically during the 1990s the robe was locally considered as an indigenous item of clothing while short hair, which was worn by Lifouan women in the nineteenth century, was considered a European hairstyle; for elderly women short hair was reminiscent of the imposed missionary rule, while for younger women it was a mark of westernisation. ${ }^{15}$ However, external differences between Catholic and Protestants are still present. ${ }^{16}$ For instance, during religious services, Catholic women do not cover their heads while Protestant women, especially seniors, wear a hat; in the past this was often a colourful woven basque. On less formal occasions women shield their heads from the sun using a piece of cloth.

The robe mission, made of finely woven cotton, apparently very delicate to the touch, in practice was stronger than it appeared. The range of situations in which women used the 'three buttons robe' in the 1990s was wide: from sleeping to bathing in the sea. Ernesta Cerulli writes that the work dress 'often is quite different from the ceremonial and holiday costume' (1999: 104). In the case of Kanak women this distinction does not seem to be so rigid: in the gardens women dress in very informal ways; often they wear an old robe, no longer suitable in other contexts, buttoned in front for practical reasons. In the past this distinction was more marked, because missionaries imposed white robes as Sunday best; today the difference tends to lie more at the level of manufacturing. Women's dresses, which are part of daily life clothing, are also worn on important occasions (religious functions, weddings, funerals, yam feasts, women's gatherings), assuming a strong meaning of kanak-ness. As Pohnimë emphasises the robe is included in the gifts exchanged during wedding ceremonies. But when old, worn and torn, and no longer suitable as a garment, it is still put to use as a rag until there is nothing left. The long life of the robe mission thus goes from Sunday best to service as a rag. ${ }^{17}$

Whereas in nearby Vanuatu, Bolton explains that 'soon after Independence, island dresses were officially nominated as national dress for women' (2005: 26), in Lifou the adoption of the robe mission appears to be more

15 This has changed in the last decade; wearing short hair is no longer perceived as a missionary imposition.

16 On the articulated and complex relationship between Catholics and Protestants in Lifou, see Paini 1998.

17 I have also observed people taking off their sandals and using a rag from an old robe mission to clean their feet before entering a house. 
rooted in women's choices and desires, as confirmed by women's pleasure in showing off their best dress on appropriate occasions, for instance when going to church. ${ }^{18}$

\section{The missionary experience in Lifou}

At the turn of the twenty-first century, cloth and clothing in the Pacific began to attract more attention. In her edited volume Clothing the Pacific, which inaugurates a welcome series of books on this subject, ${ }^{19}$ Chlöe Colchester, referring to Jean Comaroff, stresses that

a distinguishing feature of the Protestant mission to the Pacific, as to other parts of the colonial periphery, was the emphasis placed on defining ordinary everyday activity, a pursuit in which the imposition of foreign practices of domesticity, home-making, dress and deportment were regarded as being as central to conversion as translating the Holy Book (2003: 2).

Colchester contrasts this with what she considers to be the ways in which Catholic missionaries would become involved with local contexts:

Catholic priests did not share this degree of concern with everyday material things since their approach to the place of objects in worship and religious practice was different, and moreover the impact of Roman Catholics was to remain small compared to that of the Protestant Evangelicals. For Protestant Evangelicals wanted the islanders' [sic] to accept not only their faith, but their way of life (2003: 2).

A caveat is required at this point before returning to clothing. Norman Etherington in the 'Afterword' to In God's Empire: French Missionaries and the Modern World (2012) supports the idea that not only British and French practices of colonial rule had more in common than was often thought, but that 'a comparable argument can be advanced for Christian

18 Nevertheless, I want to point out what could become a novel pattern of male control on female clothing, which I observed at the next-to-be Gaica’s high chief's wedding in May 2011. It was a big event, which had been prepared for a long time and was extensively covered by the media. Almost 50 years separated the wedding of the present chief from that of his first-born son. Among the many rules established for the occasion, the council of elders had decided that Kanak women 'working' at the ceremony should all wear the robe. Most young women conformed to this requirement; however, I did observe exceptions. In any case I did not read into it a moral imperative but rather a way to present themselves to outsiders.

19 It was followed in 2005 by another edited volume by Susanne Küchler and Graeme Werepart of the same 'Clothing the Pacific' project of the British Museum. 
missions in the modern colonial era. In the long run, underlying similarities outweighed eye-catching differences' (2012: 280). He points at 'striking contrasts' such as the fact that the British missionary movement was linked to a leadership imbued with faith in progress and commerce, whereas the nineteenth-century French Catholic missions recruited missionaries from rural areas and considered 'civilisation' to be part of an anticlerical agenda. But he also argues that 'the longevity and diversity of Christian missionary experience ensure that counterexamples abound' (280). Ethnographic and archival material from Lifou, as well as from other parts of the country offer one such counterexample regarding missionary activity.

In addition to the active role played in the imposition of a European dress code by the wives of Protestant pastors (see below), the Marists believed that the best way to reform Lifouans was through education. This view was voiced in their request for sisters to join them in the missions as revealed in a passage from a letter by Father Lubin Gaide to Father Victor Poupinel, Visiteur of the Socitété de Marie’s Missions in Oceania:

Without sisters we will never have Christian mothers; and without Christian mothers, we are building on kanakism, that is on the sand. We will never have Christians worthy of this name if they do not first become men. Now, they will become men only through maternal education (Gaide to Poupinel, 9 February 1872, APM/ONC 208).

The letter conveys Gaide's view on the decisive role he assigned to the presence of female missionaries; he believed that sisters could educate local women in what he considered to be good mothering practices, and that this process was essential for achieving the redemption of souls. Although Marist Fathers did not write in much detail about daily local life, a very telling example of their work, connecting specifically to the theme of this essay, comes from a letter that Father Xavier Montrouzier, who was in charge of opening the new mission in Lifou in 1858, wrote to his parents from Balade on the main island; this letter reveals unusual and unexpected details of life on the mission and shows the close link between spiritual and daily life that characterised the work of Catholic missionaries:

I would not know how to tell you, my dear parents, the happiness which I felt when I saw my old parishioners again ... Magdeleine whom I so named in honour of my mother is an excellent catechist. She knows how to read and $\mathrm{P}$ [adre] Forestier teaches her to sew, to spin, etc. A small gift from you consisting of an assortment of needles, yarn and brightly colored fabrics, 
would, I believe, sort a good effect. At the same time as we work on the conversion of the indigenous, we aim at ways to make their existence down here less miserable. P. Vigouroux, with admirable patience, trains ploughmen. P. Forestier, on his part, busies himself teaching the women to sew, to spin (Montrouzier to his family, 16 March 1853, APM/ONC 208).

Montrouzier clearly conveys the idea that the Catholic missionaries were indeed engaged in both converting and getting involved in local men and women's daily life. This account is very rich, and particularly relevant to this essay is the detail concerning a Father who teaches sewing, as well as Montrouzier's request for sewing material from home. The passage reveals an unusual practice for the time and points to the complexity of Marist attitudes to involvement in redefining indigenous daily life. Thus the claim that Catholic missionaries did not participate in rethinking local life is reductive; Catholic and Protestant missionaries were equally eager to save souls, as well as to harness the exotic and normalise it to a European order of things. Yet missionary projects had to face indigenous responses.

\section{Clothing and agency}

Continuing the dialogue with historical sources, I focus on local women's agency in connection with clothing. Missionaries, adhering to a specific moral code, made people cover themselves, trying to put an end to what they considered to be nudity (and many of their narratives refer to the indigenes' nakedness). Nine months after his arrival in Lifou, Montrouzier wrote that the most difficult obstacles to overcome were polygamy, nudity - of the most revolting kinds-superstitions' (Montrouzier to Favre, 1 January 1859, APM/ONC208). Covering nakedness then become a priority and clothing became 'an icon of conversion' (Jolly 2014: 431). Both men and women seem to have willingly adopted new ways of concealing and adorning parts of their bodies. While the former wore western-style clothes, the latter adopted loose-fitting, calf-length dresses (O'Reilly and Poirier 1953). Kanak women came to consider the robe mission to be the proper dress for specific events (see Paini 2003a). I want to elucidate the complex issue of imposition/reappropriation by widening my analysis to include other written missionary sources. 
The references found in the texts of missionary men-both Protestants and Catholics-regarding male and female clothes are vague, while the texts written by women contain detailed accounts of daily life on Lifou (see Paini 2003a, 2009). I rely on the observations of two women who spent approximately 30 years on the island, one following in the steps of the other: Emma Hadfield and Eugénie Péter. Emma Hadfield, who lived most of the years $1886-1920$ in Lifou, ${ }^{20}$ wrote about a local woman who 'from the husk of coconuts ... made herself a skirt or fringe, from five to 15 inches in depth, which she wore round the waist'. She commented that 'fashions never changed; all dressed alike', although she observed differences in clothing associated to status, such as how chiefs 'fastened their girdles differently from others, and also wore more elaborated ornaments' (1920: 35). It's interesting to see that Emma Hadfield's comments on the persistence of dressing code and the absence of local imagination were echoed a few years later by Mademoiselle Péter, as the Protestant lay missionary is still called in Lifou. The writings of Eugénie Péter $^{21}$ provide an interesting source on this subject as she underlined an analogous lack of interest in changing style of clothing, but this time she is referring to the robe mission. In an unpublished letter dated 1923, she wrote:

Women are all dressed in the same way, with a kind of a sheath dress with wide carré and puffed sleeves. This is probably still the fashion of the time of Mrs. Hadfield. I am surprised at this uniformity and that they prefer to make their dresses in this way rather than kimonos which would be nicer, cheaper, more easily made, but nothing can be done (Eugénie Péter to Mr et Mme Bergeret, 2 August 1923).

The Swiss missionary elaborated on what she perceived as Kanak women's insensitivity to innovation. Yet late nineteenth to early twenty-century photographs from the Archives in Nouméa show that change has always taken place. From these images one can infer that the materials used in the earlier dresses were woven with warps and wefts of different colours making plaid and checkered patterns, whereas the later materials were printed on solid white fabric. Still, today, many visitors to the area, in

20 Emma Hadfield came to the Loyalty Islands with her husband, the London Missionary Society (LMS) pastor James Hadfield. She became very involved in local life and published Among the Natives of the Loyalty Group (1920). Once the Hadfields left, the charge of the mission was passed on to the Bergeret couple.

21 Eugénie Péter-Contesse was born in Switzerland in 1889; she arrived in New Caledonia in 1923 as a missionary teacher for the Société des missions évangéliques of Paris. 
a very simplistic way, believe that this dress has remained unchanged. In 2001, as I wrote in my fieldnotes, a new style of yoke and lace was introduced: unlike in the past, they were in a single colour that contrasted strongly with the rest of the dress.

The quote from Péter above reveals the tension between imposition/ reappropriation which characterised indigenous contexts and enables a deeper reflection on the issue of Kanak women's agency. It reveals that Lifouan women did not always seem interested in changing their dress style, thus they did not approach every kind of imported idea on clothing with the same attitude. They had already adopted a European garment that Péter believed to be impractical, as manufacturing it required excessive fabric and time; yet her proposals, centred on a logic of saving, did not meet the favour of local women. Her suggestion of adopting a kimono at first went unheard; however, during War World II the difficulties in finding fabric did produce some changes. In a time of lack of resources, rules and practices changed, so women were allowed to go to the Sunday service wearing clothes other than the robe. As Péter wrote, 'the large dresses with carré and lots of frills have long been the only ones accepted for worship. The kimono dresses were good for working and for young girls. It is changing!' (Péter, 15 June 1941).

The term 'kimono' has become part of the vernacular language to identify a specific category of clothing; in fact in Drehu a female dress can be called kimonu or iheetr. Asked to elaborate on this difference, women explained that the former is a straight dress, with a V-neck, buttoned up the front, with or without sleeves, that is unpopular today. In a postWorld War II photograph portraying a family from Drueulu, ${ }^{22}$ the wife is wearing a kimonu. ${ }^{23}$ How this Japanese word came into Drehu and other languages of the country is an issue that is still unresolved. Iheetr, instead, is a term that refers both to the robe mission and to the modele. The latter denotes the newly fashionable pattern: a yoke, sometimes replaced with a triangular shaped one-coloured piece, from which the rest of the plain garment hangs loosely (Jeanne, Hunëtë, 22 August 2001). ${ }^{24}$

22 The original is with the family; a copy is at the Drueulu registry office.

23 The 'kimono' category of clothing appears to be common both in Lifou and the Grande Terre (Emmanuel Kasarhérou, personal communication, 6 July 2002, Vienna).

24 During the time of Madame Bergeret the mission dress was called 'Madame' (Billy Wapotro, 23 August 2001). 
Some women in the 1990s used this term to refer to the robes created by Madame Walenu's new atelier, La Perle Grise, one of the earliest Kanak sartorial enterprises.

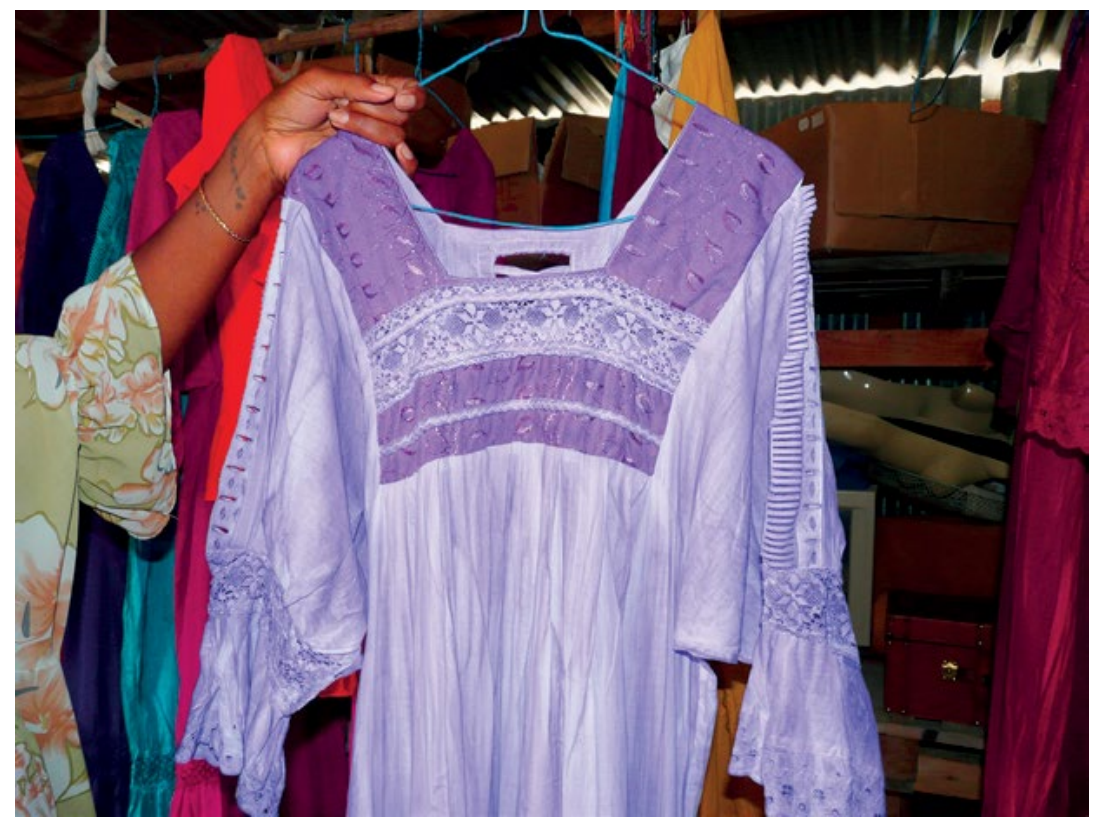

Figure 21. New style robe mission by Eseka, showing details of the top part of the dress and sleeves

Source. @ Photographed by Anna Paini, Lifou, November 2007

Agency is at issue also with naming things. The robe mission in Kanaky New Caledonia has followed an itinerary analogous to that of the term Kanak, which was initially used in a derogatory way by colonisers to refer to indigenous people. However, the latter have inverted this connotation, thus turning the word Kanak into a symbol of positive cultural identity. But metamorphoses of signs are selective. When years ago I asked Hnauleqatr to tell me about the robe mission, the elderly woman looked at Pohnimë for help; she explained that I was referring to the robe popinée. This kind of incomprehension occurred again with younger people. Invited to speak in the Primary School of Hnathalo (northern district of Lifou) about being an anthropologist and speaking in French, I referred to my research on the robe mission. The Kanak teacher kindly interrupted me, saying he had to clarify to the class that I was referring to the robe popinée, a term which is contested in the rest of the country. Returning to Nouméa from Lifou, I was sharing what my interlocutors had told me with a Kanak friend, 
Marie-Claire Beboko-Beccalossi, while she was driving us to her home from the airport. On the threshold of her house, Marie-Claire corrected me very firmly saying that I should stop referring to the dress in such a way; it was a 'robe mission' or 'robe mélanésienne'. Other friends from the Grande Terre to whom I explained what I perceived as a misunderstanding had similar reactions. To them the term popine 25 still carries a highly negative connotation, as seniors still remember it being used by French colonialists to refer in denigratory terms to young Kanak women. Back in Drueulu one afternoon the well-known Kanak singer from Lifou, Edou (alias Edouard Wamai) was visiting my host family while I was puzzling over this question of naming with her, and Edou reminded me that in 'Océanie' he sang of 'vahine popine aux milles couleurs amour sans frontière'. And this window, opened on the scene of naming, once again reveals that the experience of colonisation has marked Kanak from the two areas differently, and continues to influence contemporary practice, though for younger people this is mitigated as they have not lived the same experiences as their elders: ${ }^{26}$ novel articulations of colonial pasts and presents are taking place.

Kanak remember a time when it was forbidden to wear the robe mission. Denise Kacatr recalls that when she was young, on the Grande Terre wearing the robe during the week was forbidden, and for her this rule was a way for French institutions to 'take possession of Kanak culture' (We, 14 August 2001). In 1966 three Kanak students at the Lycée Laperouse of Nouméa (Billy Wapotro, Fote Trolue and Jimmi Ounei) demonstrated against the school rules prohibiting girls from wearing the robe and boys from wearing open sandals (Wapotro, 23 August, 2001). Although I have not yet found a written record of this vestimentary code of conduct imposed by the principal, other witnesses confirm the story. The devaluing colonial gaze on Kanak women had first imposed the robe, but in some urban situations, in particularly those connected with schools, the colonial power preferred to deny any indigenous specificity. What were the implications of this colonial measure? It was a time when also vernacular languages were banned in public places and the French

25 Popine is the Drehu spelling.

26 When I published my first article in French on the robe mission (2003a) I puzzled over the title, and following Billy Wapotro's advice I decided not to include the word popine because of its loaded history. 
colonial government was trying to stifle any outward symbol of local identity that might show an incomplete assimilation to a French order of things.

\section{La robe et la coutume}

I would like to expand on what was stressed by my interlocutors, namely that the robe mission is now part of customary exchanges by considering its role during marriage ceremonies. I'll briefly introduce the event though I do not intend to tackle all the issues involved in this complex ceremony. Qene noj, 'the way of land' and glossed in French as la coutume (custom), is opposed by Lifouans to qene wi wi, 'the way of the French'. Faire la coutume (making custom) refers to the rituals underlying daily social relations in which people exchange goods, marking these transactions of gifts and counter-gifts with speeches, that may be more or less elaborate depending on the occasion and on the setting. La coutume is considered as constituting the core of life and identity. Custom is, however, not perceived in opposition to modernity, as exemplified by the use of money in customary exchange. Significantly, la coutume in Lifou has not been widely appealed to in mounting a critique of the Christian religion (see Paini 1998).

To initiate marriage negotiations, the groom and his family make a visit to the family of the bride-to-be to take kuie june hmala (thanks for acceptance of a marriage proposal), a gift consisting of money. Unlike other exchanges, this transaction is made in private; the amount involved varies, depending on financial possibilities. In May 1990, I was able to attend such a ceremony in Drueulu, which involved partners from the same villlage. It took place in the evening and lasted half-an-hour. When the man's family entered the hut they first gave 3,000 French Pacific Francs (CFP) for qëmek $;^{27}$ opening the way to two transactions: 100,000 CFP for kuie june hmala and, as the unmarried couple had a child, a further 50,000 CFP as otren hne la nekönatr (literally, bond with the child) to legitimise the paternity: hnöth la nekönatr (literally, to tie the child). The woman's family accepted and presented its monetary counter-gift

27 A gift of money is required as an opening gesture in a wide range of contexts; the amount depends on the importance of the occasion. The French Pacific Franc (CFP) is the currency of the country. At the time the CFP and the French Franc (FF) had fixed parity: 100 CFP was equal to 5.5 FF. Today it has fixed parity with the Euro. 
$(20,000$ CFP). Each customary gesture was accompanied by a very formal speech. The exchanges over, the date of the marriage was communicated to the bride's family, though unofficially it was already known. In Lifou at the time of my first fieldwork both women and men admitted that the amount of money circulating on these occasions was increasing and perceived contributions to weddings were becoming too competitive. Both criticised the high expectations and yet attempts by the customary authorities to set limits to the trend toward excessive commoditisation have not been too successful. ${ }^{28}$

The work done by the bridegroom's party for the bride's family was explained by Sipo as showing the importance of women within custom. Marriages are planned a year ahead of time allowing members of the kin group to plant yams and other crops for exchanging and for the wedding meals. For the two-week period of preparation, a large group of people will eat together every day, the women being responsible for organising the food. Both men and women of the kin group are also engaged in other tasks, such as determining the monetary contributions expected from each branch of the group, and preparing the contents of the valise (suitcase). Several days before the bride is accompanied by her family to the bridegroom's place, people arrive to bring their tro (customary marriage gifts), consisting of money, cloth, yams and other staple foods. Groups are welcomed one at a time, so if several groups arrive at the same time they have to wait their turn. After these gifts and counter-gifts have been made (accompanied by formal speeches from both parties), the group is invited to eat. These contributions, together with those of mathin (mother's brother) and ifaxa (real and classificatory married sisters), are assembled, and at the end of the ceremony they will be divided into three parts: pua, for the bride's family to be divided among the guests; wenehleng, for the parents of the bride (or, as some women say, for the mother of the bride); and hna hetrenyin, which goes to the newly wed couple. A further category of gift is ihehe; it consists of western goods for the household and some money and is given by guests of both sides to the couple. Generally at the end of a wedding, the organisers announce the amount of money that was contributed and how it was divided into the three categories. The success and the status of the ceremony (and thus of

28 In 2014 a new set of written regulations were codified in Lifou. It is too soon to determine their impact and long-term effects on wedding practices. 
the family) tends to be judged on these terms. When people comment on how much money has been raised and thus on that particular wedding ceremony's importance, they will not include the ihehe.

If the bridegroom's family is responsible for raising the money and organising the ceremony, going to a marriage on their side, lapa i trahmany, entails 'work', the bride's group will instead be considered as honoured guests: they are invited to 'come and eat'. However, it will be up to that group to determine the number of peleitr (plates); that is, the number of formally invited guests. To be included in the guest list does not simply mean to be given precedence in eating on the day of the wedding manger à la premierè table (eating at the first table). If the bride's lineage decides to distribute 60 'plates', it means that the pua will be divided into 60 parts. Pua consists of money, food, fabrics and clothes contained in the valise that the bride's family will receive at the end of the ceremony. The valise (today a large wheeled suitcase) is prepared by the women and filled with different kind of clothes, western and local; a certain number of robes mission is always included. The presence of the robe also characterises other exchanges of the wedding ceremony, such as the gifts brought by each party to the wedding. Further, when the bride arrives with her family to the groom's place, she sits in front of her mother-in-law wearing two mission dresses, she takes one off and gives it to her. The robe mission plays an important role also as the dress worn by women on the groom's side in specific parts of the event. In fact, a senior woman is appointed to decide months before on a specific style of robe-its colour, trim, type of sleeves - and commission an artisan to create the dress in different sizes to be bought by female relatives for the ceremony of welcoming the bride. The order often is for 50 or more dresses. It is evident that the robe mission mediates different phases of this very important life-cycle ceremony, and in this respect I have observed continuity since 1989.

\section{New female entrepreneurship: A story}

Chlöe Colchester introduces the edited volume Clothing the Pacific by stressing that Pacific women's contemporary dress, known as 'Mother Hubbards', 'seems stuck in the nineteenth century ... an indication of the way that women's dress has lagged behind other social innovation' (2003: 1). Again, a counterargument can be shown from Lifou. 
Up to the late 1990s the dress could be worn buttoned at the front or at the back. As I have already remarked, this article of clothing has never been conceived of in a rigid way. Aesthetics in the 1980s and 1990s favoured large floral prints, the new fashion prefers single colours often with a contrasting white design; frequently the dress is made with white cotton fabric dyed one colour with a stencilled design and buttons are no longer found on the back of the dress. The raglan sleeve attaches to the yoke and the fabric is slightly pleated and flows from it. A recent innovation is the addition of an invisible pocket on the right side that can be used to carry keys or a mobile phone. The robe persists as a mode of dress regardless of all these stylistic innovations (Figure 21).

The mission dress, as we have seen, leaves plenty of room for creativity, imagination and taste. I started doing fieldwork in Lifou in 1989, and between periods of fieldwork I saw new models, sometimes very popular for one season only. But in more recent years a new phenomenon relating to female creativity has arisen, making these changes increasingly visible. Some Kanak women have opened their own small tailoring ateliers, giving rise to a new trend which has rapidly spread; these have incentivised greater inventiveness than in the past, from the choice of fabrics (new materials and designs) to the sleeves and other stylistic details. These new creations have immediately aroused the interest of Islander women. I have pointed out how in the past differentiation tied to place or religious affiliation was signalled by clothing; in recent years a new element has come into play, the style of the atelier where the dress is made. This is a change that affects both urban and rural contexts.

In fact, until the second half of the 1990s, women would buy their robes mainly from Chinese shops in the capital. In recent years, Kanak women have become involved with tailoring, producing a good level of craftsmanship, with affordable prices for the local market, although higher than those charged in Chinese shops. A flourishing entrepreneurship has risen centred on the mission dress. Forerunner of this new involvement of Kanak women in dress-making has been the experience of the atelier La Perle Grise in Nouméa in the 1990s. Its impact was more limited, affecting primarily women in the capital.

Today, women have put forward their skills in tailoring by creating their own models, which quickly become very popular. Kanak women design, manufacture and market both locally and across islands. The new Kanak designers have indulged in designing and creating different models, 
whose originality is distinguished by certain elements such as the material utilised (from Indian fabrics to the yoke from Caribbean tissues), the type of sleeves, and the neckline.

In 2005, 2007 and again in 2009, I had long conversations with some of these dressmakers in Lifou and in Nouméa. When discussing the extent to which they could push to introduce creative changes on the dress while continuing to define it as a robe mission, I obtained different answers. The dress and sleeves must remain wide. One of the dressmakers, after some hesitation, clarified that an element that makes the difference are the pockets; if you put in pockets you 'ruin everything, it is the French' (Sélèké). Yet in those years some women wore robes with a single pocket; more recently a second pocket was added to some new models. Another element that is considered incompatible with a robe is the belt. A feature that has not been modified by the new dressmakers is the length of the robe. All in all, the sartorial code has changed and the dress has been revolutionised: different, wider necklines which do not require buttons and sleeves that may have openings to reveal one's shoulder or arm. I should add that these new robes do not have an interchangeable front and back like the old ones, an element which gave the wearer a further possibility of choice. In all cases, these contemporary outfits created and made by Kanak dressmakers continue to be recognised as a robe.

Agency is expressed both by the women who have taken a new direction in their work, through their creativity and inventiveness, and by those who have started to buy from them. There was a kind of contagious word of mouth: not only women from Lifou wore outfits made in these ateliers, especially on formal occasions. They began to be able to recognise the dressmaker who had designed the robe from its style; and some of these ateliers were struggling to keep up with orders, especially during the period of the marriage season.

Whereas in the 1990s in Lifou the French wedding dress was most popular, in the early twenty-first century a new fashion trend has emerged. Many brides to be choose to have their dress made by one of these ateliers because their style is considered to be more local and personal. The dresses chosen by each side of the wedding party to wear during the ceremony, clearly marking those belonging to the bride's or the groom's side, are also increasingly ordered from these dressmakers. These new ateliers have the advantage that clients in the rural areas can discuss with the tailor the colour and style of their choice. 


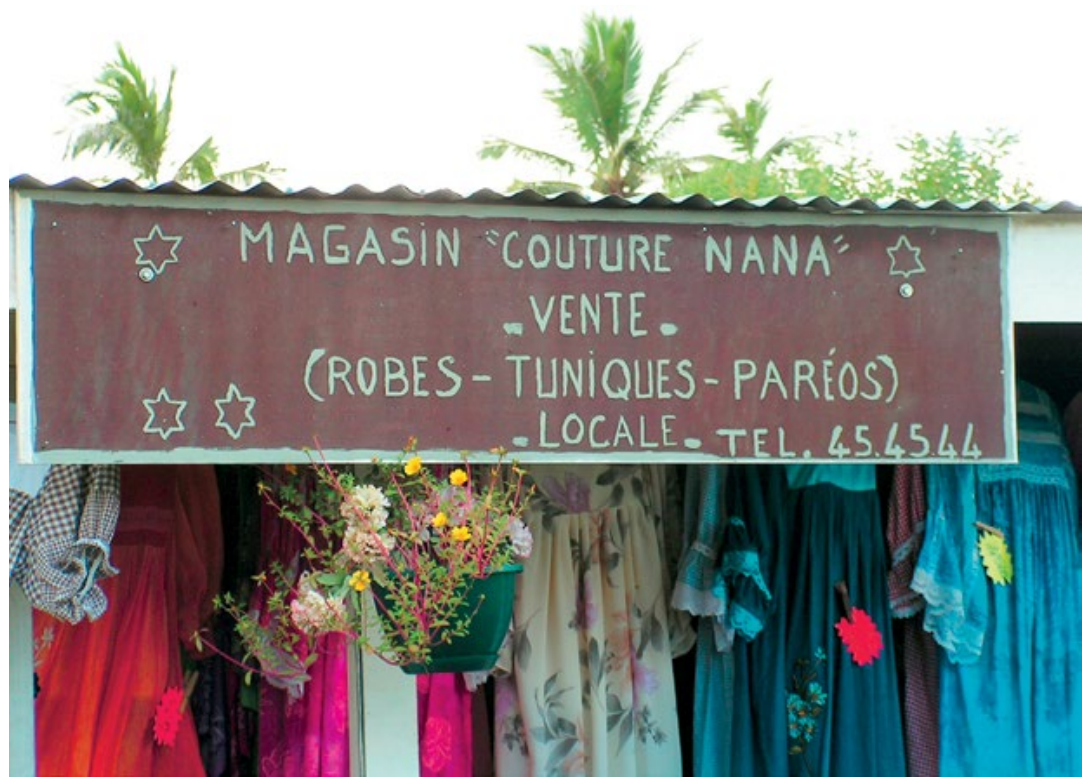

Figure 22. Magasin 'Couture Nana', Nang, Lifou

Source. (c) Photographed by Anna Paini, Lifou, 27 March 2005

To illustrate all these innovations, I present here a story collected in Lifou in March 2005. Two years earlier Sélékè ${ }^{29}$ had opened 'Couture Nana' (Figure 22) after a successful request for assistance to the Province des îles in order to carry out a project she had had in the pipeline for some time. I interviewed her in her atelier in Nang, in the northern part of Lifou. She agreed to answer my questions at the same time as serving her customers. She had started to learn how to sew as a child, both at home and in school. Later she learned from her mother-in-law, who was a skilful seamstress. One of the walls of the room that she converted into her atelier was covered with photographs of her creations. She emphasised the choice of new fabrics, especially plaid and checked material, which she was inspired to use for robes mission after seeing them in a fabric store in Nouméa. She argued that it was a novelty: 'it was my idea' that soon became fashionable. Sélékè had started to make these robes à carreaux in June 2004; less than a year later she had already made and sold approximately 800 of them. Besides her husband, who helped her in the different phases of the hand dyeing process, she also had the help of a seamstress.

29 This story has already been introduced in Paini 2009. 
The cotton and cotton-synthetic fabrics arrived from Nouméa. Most of the time she placed her orders by telephone; in cases of larger quantities they were shipped by sea, otherwise by air. 'I do not design, I look at the fabric and cut,' Sélékè recounted. And, speaking of the demands of some customers to make them a dress according to a certain style, she insisted: 'I do not like to copy but to create models'; she told me that she had refused to follow a customer's request because the idea was taken from another stylist. Her clients were from Lifou as well as from nearby Maré and also from the capital, where two shops were selling her robes. The path followed by her creations provides an interesting situation in which dresses are locally produced in a rural area and from there reach the capital to meet the urban demand. This reverses the traditional commercial route of the robes made in the capital and sold on the islands.

Sometimes clothes were hand dyed with stencilled patterns or embroidered designs. She would agree to dye robes, only if she received an order of 15-20. When choosing colours, ordered in Nouméa, Sélékè explained that she took into account the 'desires of women'. The designs were hand-made individually for each robe, but in the case of group orders for weddings she would use a pattern to ensure a more homogeneous outcome. Her spirit of innovation led her to experiment with new techniques for drying hand-dyed robes even in the absence of the sun. The price of a robe depended on the hours of work - the average price was around 5,000/6,000 CFP. 'The dresses for the coutume tear easily, mine are more expensive', however, she points out, they 'last longer'. Though she was busy that day, she was proud to tell me that 'women prefer to buy in Lifou. When they go to Nouméa, women know when a dress has come from Lifou. The Chinese have always the same model, with a narrow neck'. Sélékè relates an experience she had in town: 'The check material dress ... I went into a shop in Nouméa and I was told: "Lady, this is a new model, it has just came out". And I retorted: 'That model comes from Lifou'. But then she added: "That's the way it is in commerce".' Sélékè claimed to have solved the problem of imitation by resorting to labels, which she had just ordered from Thailand. 


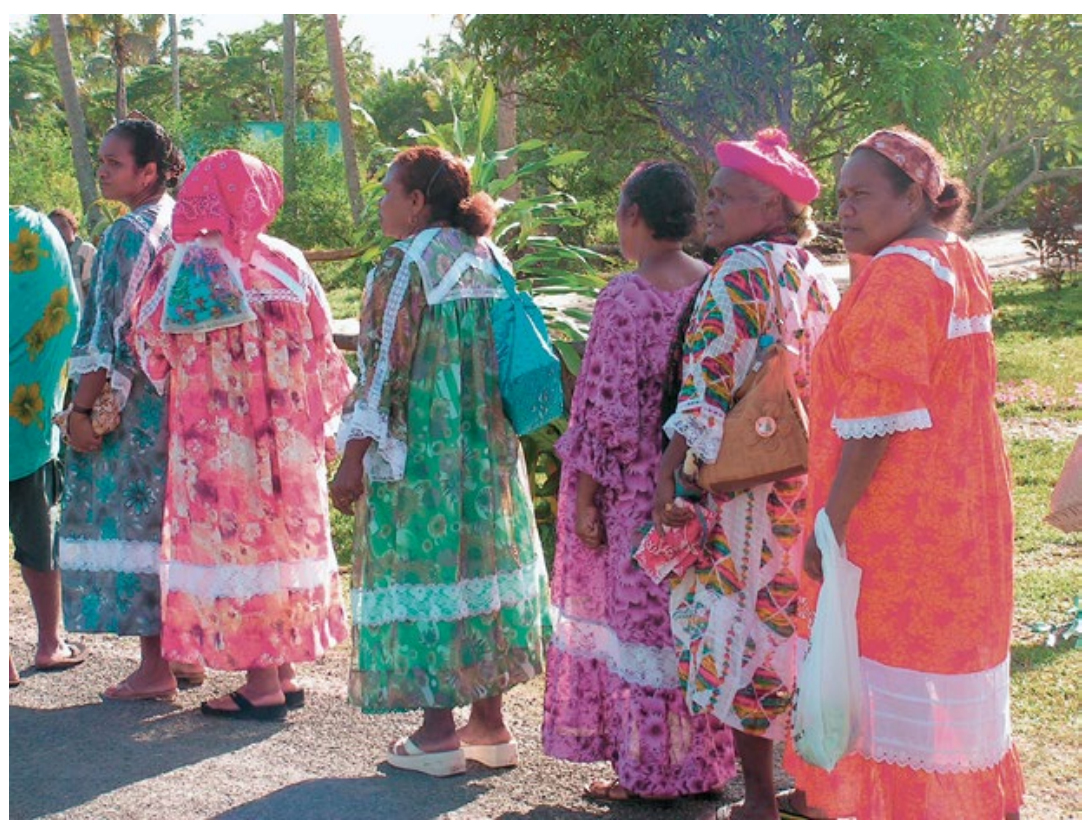

Figure 23. Old and new robes, Protestant convention, Kumo, Lifou

Source. (C) Photographed by Anna Paini, 27 March 2005

Asked to indicate the terms she used to talk about the robe, Sélékè specified: 'Robe à carreaux, plain simple robe, robe dyed with dentelle, double dress ... You know "mission" is a bit .... She left the sentence incomplete. Robe popinée instead returned several times during the conversation. A customer from Maré who followed part of the interview responded without hesitation that she preferred the expression robe popinée because 'it comes across as more related to Kanak women', while robe mélanésienne 'sounds too French'. She admitted, however, that she was aware that on the Grande Terre the term had a pejorative connotation, but insisted that this was not the case on the Loyalty Islands.

The use of the robe mission has expanded; even girls and young girls are increasingly wearing it on important occasions. Thus, alongside the standard sizes - 1, 2, 3, i.e., small, medium, large ${ }^{30}$ — the new dressmakers are beginning to make sizes for girls. Work is guaranteed throughout the year as there are plenty of opportunities to buy a new robe: before and during the Easter Protestant convention (Figure 23); on the occasion of

30 Lately also size 4. 
marriages; and for various other celebrations. On funeral occasions, some women purchased from her both the garment they were intending to wear to the event and those for ceremonial exchanges. In this case women chose ready-made dresses, while for weddings the choice was more personalised.

Sélékè took part in three defilés (fashion shows), one in downtown Nouméa during a promotional event organised by the craft associations. Among the customers there were some tourists, but 'they do not choose the check materials because they view [them] as coming from the métropole [France], they prefer the dyed dresses, the pareos'. ${ }^{31}$

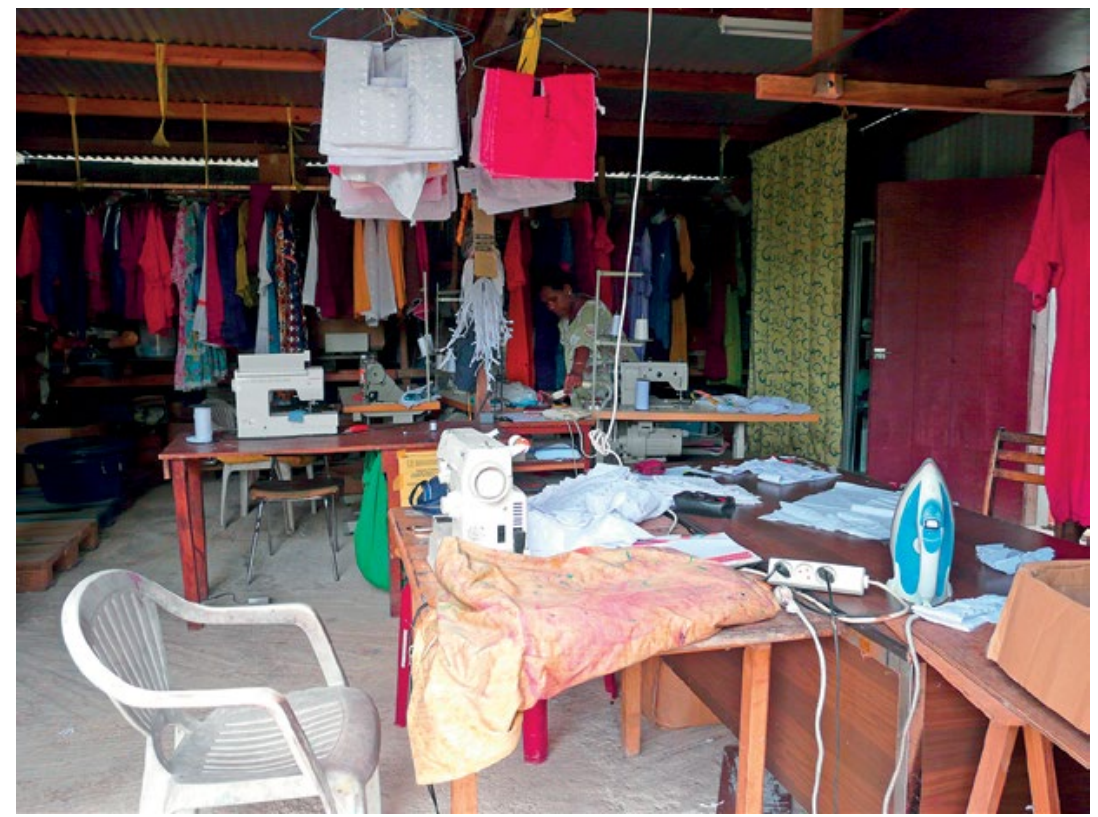

Figure 24. The worktable of Eseka's atelier, Lifou

Source. (C) Photographed by Anna Paini, 8 November 2007

31 When I returned to Lifou the atelier was closed. Sélékè had died after a long illness. Eseka, one of the most succesful business women from Lifou, who today runs a big atelier in town, told me that she was inspired by Sélékè’s example. (Eseka, June 2015; see Figures 24 and 25). 


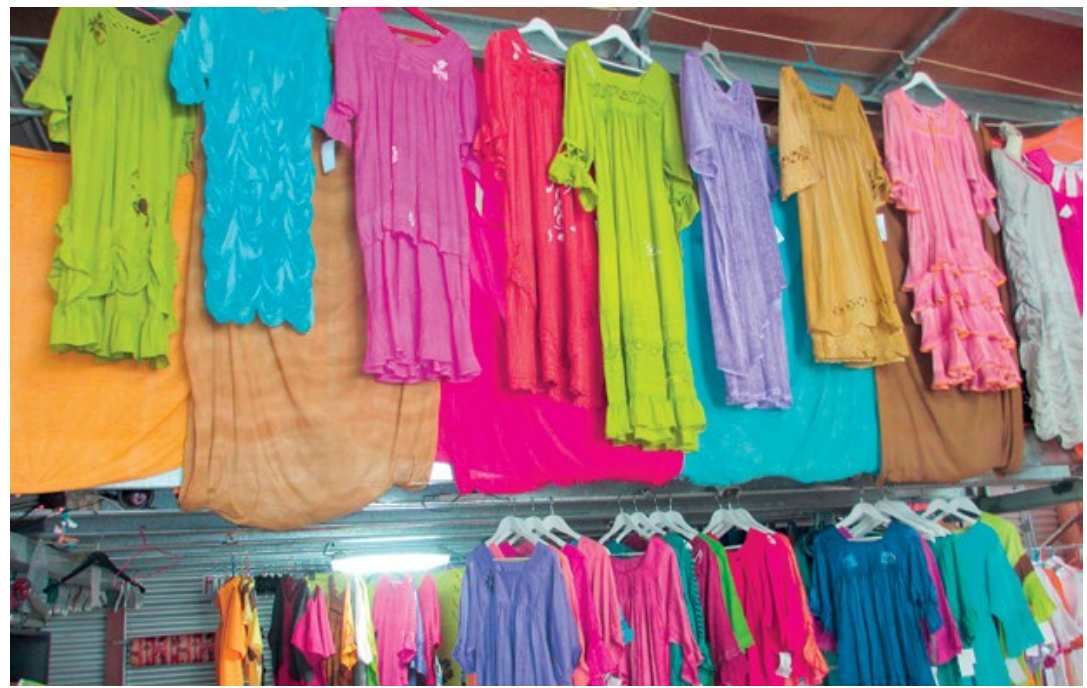

Figure 25. Eseka Couture, Nouméa

Source. (c) Photographed by Anna Paini, 5 June 2015

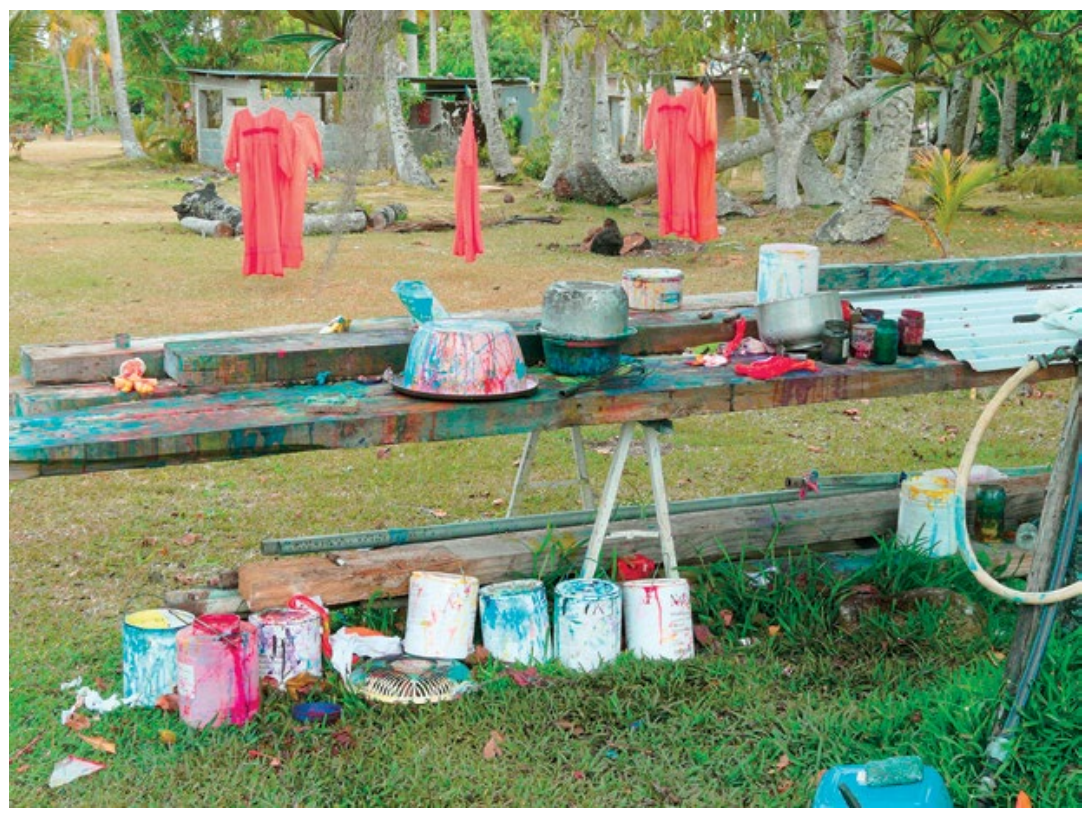

Figure 26. Hand-dyed robes drying in the sun, Hapetra, Lifou

Source. (C) Photographed by Anna Paini, 11 November 2009 


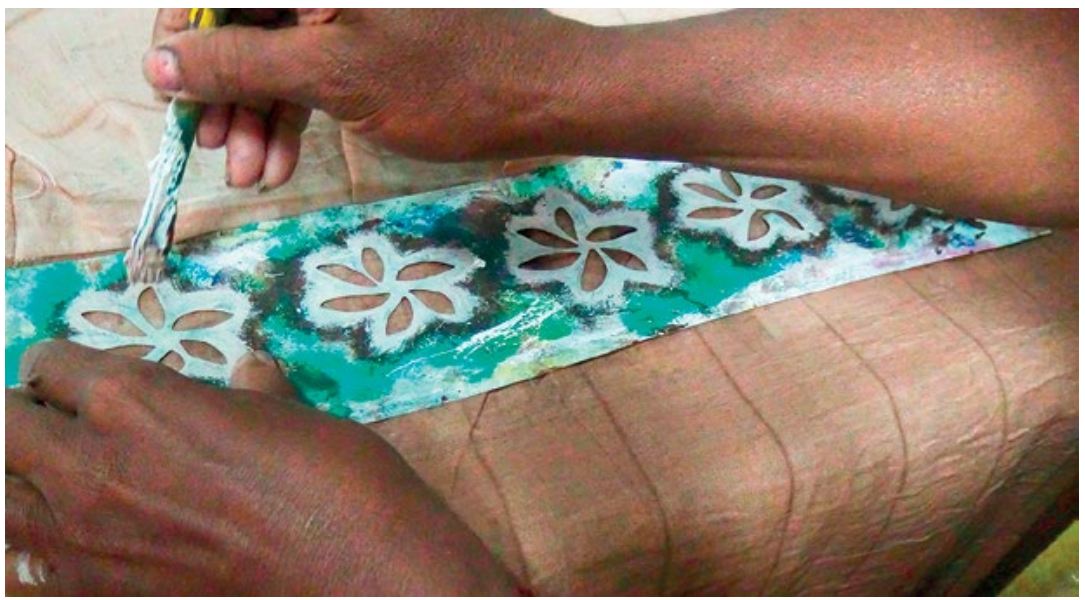

Figure 27. Hand painting flowers on a hand-dyed robe mission, 'Naji Couture' by ljane, Hapetra, Lifou

Source. (c) Photographed by Anna Paini, 1 June 2015

\section{Conclusion: 'De la robe mission à la robe kanak'}

The new interest in the robe has spread over to the Grande Terre. More and more Kanak women are choosing to sew not just for themselves but for other women, starting small businesses (see Figures 26 and 27). In 2010, I attended the second 'Fête de la Robe Mission' in Koohné, organised by the Northern Province. Waimalo Wapotro (2010) and I were invited to talk on the robe mission. ${ }^{32}$ Kanak women determinately voiced their concern regarding the Nouméa shops' practice of imitating their models. They considered their handiwork as a 'creative endeavour' and asked the governmental officers present what could be done at the central level in order to defend what they perceived as their 'intellectual cultural propriety' rights (see Pigliasco, Chapter 9, this volume), and to put in place a system enforcing the protection of the robe made by Kanak women. The government representatives were taken back by such an unexpected vehement request.

32 Waimalo Wapotro had given an important talk on the history of the dress at the Jean-Marie Tjibaou Cultural Center in 2003, in the same year my article on the robe mission was published in Journal de la Société des Océanistes (JSO). This conference in 2010 was the first occasion in which we were both involved (see Mwà Véé 2010). 
The perception of the mission dress as a colonial garment, that for a long time connoted the Grande Terre where the colonial influences have been more intense, is giving way to a different one now that Kanak women are designing, manufacturing and marketing the dress themselves. Thus moving along 'tides of innovation', the robe mission has been accorded a novel local content and thus is becoming the kanak female dress across the country; both older and younger women acknowledge it as a symbol of pride.

I do not want to convey a false image that all Kanak women make the same choices. In the early 1990s I wrote that dress codes in Nouméa had changed, they were more relaxed, especially for young women who often wore trousers both at home and outside. Older women instead still wore the mission dress to go to work or to go out to places such as the post office or to bingo. They wore the same style of dress regardless of the public space they moved in. For important events, such as a wedding, however, even a Lifouan girl in Nouméa would wear a robe mission (Paini 2003a). Today, more adult women wear pants combined with a long, loose top, often in the style of a robe mission (see Cummings 2013; Jolly 2014). Yet, for important occasions adult Lifouan women will choose a robe, which they consider the proper way to dress. Nevertheless, the mission dress has been transformed by Kanak women into a versatile garment, worn on formal and informal occasions. Its versatility is such that it has been used by players of female cricket teams at all levels. Their official uniform above the sneakers is the mission dress in the colours of the village team they belong to: Drueulu, for instance, chose blue and white; the neighbouring villages of Hapetra and Wedrumel respectively yellow-green and greenwhite-red. The mission dress is thus associated with the most popular national sport among Kanak women and at the same time its colours distinguish the teams on the field, enabling players and fans to identify with their team.

The polysemic dimensions of this dress show that women can turn to it in articulating the tension between belonging and difference. Locally made, the robe is now considered as an element of belonging that, depending on the context and the strategies adopted, can emphasise either the place one comes from or a common feeling of being Kanak, or both. At the conclusion of the General Assembly celebrating 20 years of activity of 
the women's movement 'Smiling Melanesian Village', ${ }^{33}$ which was held in Drueulu (Lifou) in February 1992, women organised a march through the village that saw 200 participants parading in robes mission: each group adopted a chosen colour code and pattern (see Paini 2003a and 2003b). Just like the Kanak delegation present at the international event Terra Madre in Turin chose a white and red floral fabric, in local, regional and international arenas, the fabric used is chosen for each occasion. However, if the fabric connects to a specific place and thus emphasises locality, the dress itself emphasises communality; thus multiple threads of meanings are woven into this garment.

Gradually Kanak women have transformed the robe, adapted it to their taste and made it their own 'traditional' dress in which they recognise themselves. Annamaria Rivera's assertion (2005) that the symbols and practices of clothing and the meanings that they take on depend on how they are acted out in a given historical situation, is relevant here; it helps us to understand the specific colonial experiences lived in different parts of the country, and the ways in which these experiences have been locally elaborated over time: a new rearticulation has taken place in the context of the new female creativity and entrepreneurship. In 2008 a project titled 'Popinée', centred on a dance by Kanak choreographer Richard Digoué, was performed at the Musée de Nouvelle-Calédonie. The subject of Kanak women's empowerment was explored through the history of the mission dress. On that occasion Marie-Solange Néaoutyne, director of the Museum, wrote a poem which she entitled 'Popinée'; it was published in the special issue of Mwà Véé (2010: 69) and dedicated to the robe. In her poem she emphasised the changing status of women wearing the dress: 'from submission to creation' and endorsed the switch 'de la robe mission à la robe kanak'; her phrase was then borrowed as title for the special issue. Further, the robe has been included in the second Festival International des Textiles Extraordinaires (FITE); the textile exhibit Renaissance opened at the Bargoin Museum in Clermont Ferrand in 2014 (Athenor 2014) and moved to Manila at the Metropolitan Museum (MET) in 2015 (Figure 28). ${ }^{34}$

33 An association of Catholic Kanak women spread throughout the country.

34 I have kept the robes mission purchased or received as gifts through the years and I loaned them to the Bargoin Museum in Clermont Ferrand and to the Metropolitan Museum of Manila for the Festival International des Textiles Extraordinaires (FITE) in 2014/2015 (see Figure 28). 


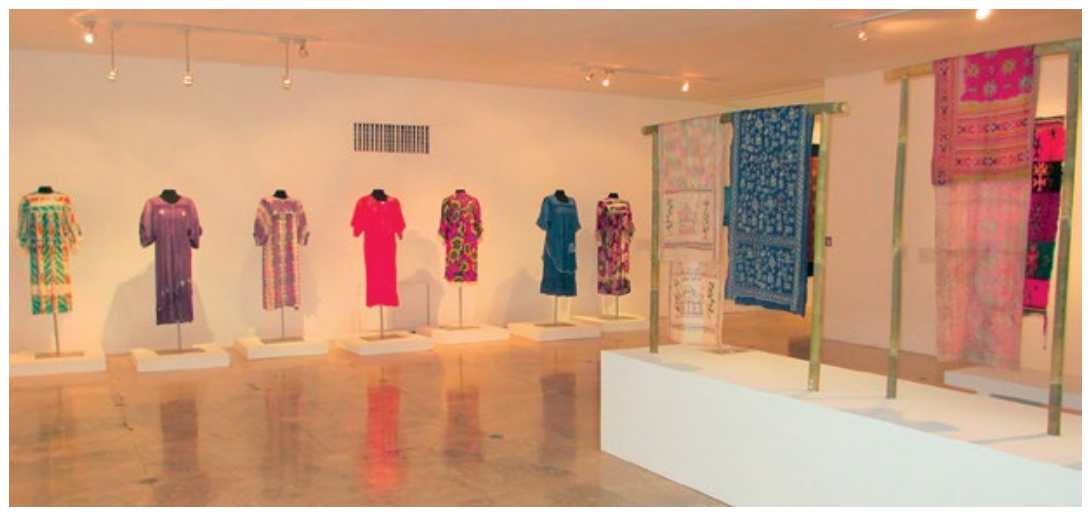

Figure 28. Festival International des Textiles Extraordinaires (FITE), Metropolitan Museum of Manila (MET), Manila

Source. () Photographed by Anna Paini, 9 July 2015

In recent years Kanak female agency has taken on new forms: on the one hand, seamstresses/dressmakers/artisans/artists have created a new female entrepreneurship, spreading from Lifou to the rest of the country; on the other hand, female customers have chosen clothes in the new styles, purchasing them from the Kanak dressmakers' ateliers, thus provoking a snowball effect. Symbols and practices in clothing were re-contextualised in the past and continue to be rearticulated in the present, even if the pace of innovation is faster in the twenty-first century.

It is still too early to predict if the successful ventures of these women will lead to more radical changes, for now they all say: 'It is always the robe' that is invested with local value. The notion of 'pragmatic creativity', defined by Heather E. Young Leslie and Ping-Ann Addo as 'a way of seeing, being in, and fashioning the world that is alert, flexible, pliable, open to modification, adaptation, re-adaptation' (2007: 12), surely applies to Kanak women who have resignified a colonial object turning into a cultural one by transforming it into an interisland and interconfessional cultural object, negotiating its meanings, turning it into something they appreciate in terms of value as well as of aesthetics. Re-dressing signs and designs, Kanak women consider the robe mission as an expression of a deep-rooted sense of place, but at the same time also an expression of routedness, of a mobile interplay with other times, places and people (Clifford 2001). 


\section{Acknowledgements}

This essay relies on material collected during various periods of fieldwork in New Caledonia. I thank the Kanak women of Lifou, in particular of Drueulu, who once again have agreed to share with me their experience and their knowledge. I am particularly grateful to Sélékè, Eseka and Ijane for allowing me to learn from them. The robe mission has already been the focus of previous works (Paini 2002, 2003a) which only partially tackled the issues developed here, the result of further research on the topic. My long article in Italian (2009) begins to address Kanak women's recent engagement with entrepreneurship. A more recent contribution (Paini 2012) deals instead with the processes of naming the dress. Missionary correspondence was consulted in the Archives of the Marist Fathers in Rome. I thank archivist Padre Carlo Maria Schianchi for his invaluable help. I also thank the late Marie-Claire Beboko-Beccalossi, Bess Flores, Elisabetta Gnecchi-Ruscone, Giuliana Sellan, Vanessa Maher, and Gabriela Vargas-Cetina. Each of them knows what I owe them. I am also grateful to Billy Wapotro. A special thanks to Barbara Setsu Pickett for comments on clothing construction. Field research carried out in 2005, 2007, 2009, 2011 and 2015 was supported by the University of Verona.

\section{References}

\section{Archival repositories}

APM, Archives of the Marist Fathers, Rome, ONC 208, missionaries personal dossiers, Lifou.

\section{Books and journals}

Athenor, Christine. 2014. Renaissance, Catalogue HS Projets, Musée Bargoin and ville de Clermont-Ferrand, Aubière: Drouin.

Bensa, Alban and Isabelle Leblic (eds). 2000. En pays kanak. Ethnologie, linguistique, archéologique, histoire de la Nouvelle-Calédonie. Paris: Éditions de la Maison des sciences de l'homme. 
Bensa, Alban, Kacué Yvon Goromoedo and Adrian Muckle (eds). 2015. Les sanglots de l'aigle pêcheur. Nouvelle-Calédonie: la guerre kanak de 1917. Toulouse: Anacharsis Éditions.

Bolton, Lissant. 2005. 'Dressing for transition: Weddings, clothing, and change in Vanuatu'. In The Art of Clothing: A Pacific Experience, ed. Susanne Küchler and Graeme Were, pp. 19-31. London: UCL Press.

- 2003. 'Gender, status and introduced clothing in Vanuatu'. In Clothing the Pacific, ed. Chloë Colchester, pp. 119-39. Oxford: Berg.

Cerulli, Ernesta. 1999. Vestirsi spogliarsi travestirsi: come quando perché. Palermo: Sellerio.

Clifford, James. 2001. 'Indigenous articulations'. The Contemporary Pacific 13(2): 468-90. doi.org/10.1353/cp.2001.0046.

Colchester, Chloë. 2003. 'Introduction'. In Clothing the Pacific, ed. Chloë Colchester, pp. 1-22. Oxford: Berg.

Colchester, Chloë (ed.). 2003. Clothing the Pacific. Oxford: Berg.

Colombo Dougoud, Roberta. 2002. 'Ricerca sul campo. Istruzioni per l'uso'. In La terra dei miei sogni. Esperienze di ricerca sul campo in Oceania, ed. L. Brutti e Anna Paini, pp. 48-69. Roma: Meltemi.

Cummings, Maggie. 2013. 'Looking good: The cultural politics of island dress for young women in Vanuatu'. The Contemporary Pacific 25(1): 33-65. doi.org/10.1353/cp.2013.0007.

Douglas, Bronwen (ed.). 2003. Women's Groups and Everyday Modernity in Melanesia. Special issue of Oceania 74 (1-2).

—. 2002. 'Christian citizens: Women and negotiations of modernity in Vanuatu'. Contemporary Pacific 14(1): 1-38. doi.org/10.1353/ cp.2002.0007.

- 1998. Across the Great Divide. Journey in History and Anthropology. Amsterdam: Harwood Academic Publisher. 
Etherington, Norman. 2012. 'Afterword'. In In God's Empire: French Missionaries and the Modern World, ed. Owen White and J.P. Daughton, pp. 279-301. New York: Oxford University Press. doi.org/10.1093/ acprof:oso/9780195396447.003.0013.

Hadfield, Emma. 1920. Among the Natives of the Loyalty Group. London: Macmillan.

Hereniko, Vilsoni. 2005. 'Dressing and undressing the bride and groom at a Rotuman wedding'. In The Art of Clothing: A Pacific Experience, ed. Susanne Küchler and Graeme Were, pp. 103-109. London: UCL Press.

Jolly, Margaret. 2014. 'A saturated history of Christianity and cloth in Oceania. Divine Domesticities: Christian Paradoxes in Asia and the Pacific, ed. Hyaeweol Choi and Margaret Jolly, pp. 429-54. Canberra: ANU Press. Online: press.anu.edu.au/publications/divinedomesticities (accessed 29 August 2016).

. 2012. 'Material and immaterial relations: Gender, rank and Christianity in Vanuatu'. In The Scope of Anthropology: Maurice Godelier's Work in Context, ed. Laurent Dousset and Serge Tcherkézoff, 110-54. Method and History in Anthropology 23. Oxford: Berghahn.

—_. 2003. 'Epilogue'. In Women's Groups and Everyday Modernity in Melanesia. Special issue of Oceania, ed. Bronwen Douglas, 74(1-2): 134-47.

—_. 2001. 'On the edge? Deserts, oceans, islands'. The Contemporary Pacific 13(2): 417-466. doi.org/10.1353/cp.2001.0055.

_- 1991. "'To save the girls for brighter and better lives": Presbyterian Missions and women in the south of Vanuatu'. Journal of Pacific History 26(1): 27-48. doi.org/10.1080/00223349108572645.

Jolly, Margaret and Martha Macintyre (eds). 1989. Family and Gender in the Pacific. Cambridge: Cambridge University Press.

Kirshenblatt-Gimblett, Barbara. 1998. Destination Culture: Tourism, Museums and Heritage. Berkeley: University of California Press. 
Kopytoff, Igor. 1986. 'The cultural biography of things: Commoditization as process'. In The Social Life of Things: Commodities in Cultural Perspective, ed. Arjun Appadurai, pp. 64-91. Cambridge: Cambridge University Press. doi.org/10.1017/CBO9780511819582.004.

Küchler, Susanne and Graeme Were (eds). 2005. The Art of Clothing: A Pacific Experience. London: UCL Press.

Leblic, Isabelle. 1998. 'Lévolution des techniques de pêche en NouvelleCalédonie'. Techniques et Cultures 12: 81-119.

Leenhardt, Maurice. 1978. 'Pourquoi se vêtir?' Journal de la Société des Océanistes 34(58): 3-7. doi.org/10.3406/jso.1978.2960.

MacFarlane, Samuel. 1873. The Story of the Lifu Mission. London: Nisbet.

Merle, Isabelle. 2002. 'Retour sur le “Code del'Indigénat": réflexions autour des principes répressifs dans l'Empire français'. French Politics, Culture and Society 20(2): 3-15. doi.org/10.3167/153763702782369803.

Milie, Imelda and Anna Paini. 1996. 'Ka xep qa hnagëje (everything that comes from the sea); or foreignness as articulated by Lifuans'. Paper presented at the European Society for Oceanists conference, Copenhagen, 13-15 December.

Muckle, Adrian. 2011. "Native", "Immigrants" and "libéré": The Colonial Regulation of Mobility in New Caledonia'. Law Text Culture 15: 135-161.

Mwà Vée, Revue culturelle kanak. 2010. De la robe mission à la robe kanak. Special issue 69.

Mwà Véé, Revue culturelle kanak. 2001. Vision poétique du monde. Écritures kanak, calédoniennes et océaniennes. Special issue 33.

O'Reilly, Patrick and Jean Poirier. 1953. 'L'évolution du costume'. Journal de la Société des Océanistes 9: 151-69. doi.org/10.3406/jso.1953.1775.

Paini, Anna. 2012. 'I processi di indigenizzazione nelle pratiche culturali e linguistiche dei Kanak di Lifou'. Ethnorêma 8: 1-15. Online: $\quad$ www.ethnorema.it/pdf/numero\%208/05\%20Paini.pdf (accessed 29 August 2016). 
__ 2010. 'Rhabiller les symboles: robes mission et femmes en pays Drehu'. Mwà Véé 69: 6-9.

—_. 2009. 'Risemantizzare vecchi e nuovi simboli. Robe mission e imprenditorialità delle donne kanak (Nuova Caledonia)'. In Antropologia dell'Oceania, ed. Elisabetta Gnecchi-Ruscone and Anna Paini, pp. 237-63. Milano: Raffello Cortina Editore.

—_. 2007. Il filo e l'aquilone: I confini della differenza in una società kanak della Nuova Caledonia. Torino: Le Nuove Muse.

__. 2003a. 'Rhabiller les symboles. Les femmes kanak et la robe mission à Lifou, Nouvelle-Calédonie’. In Nouvelle-Calédonie 150 ans après la prise de possession. Special issue of Journal de la Société des Océanistes, ed. Isabelle Leblic, 117(2): 233-53.

—_. 2003b. "'The kite is tied to you". Custom, christianity and organization among Kanak women of Drueulu, Lifou'. in Women's Groups and Everyday Modernity in Melanesia. Special issue of Oceania, ed, Bronwen Douglas, 74(1-2): 81-97.

—_. 2002. "Ri-abitare il corpo. Le donne kanak e la "robe mission" a Lifou (Nuova Caledonia)'. DiPAV Quadrimestrale di psicologia e antropologia culturale 3: 79-92.

__ 1998. 'Praying Samoa and praying Oui-Oui. Making Christianity local in Lifu (Loyalty Islands)'. In Common Worlds and Single Lives: Constituting Knowledge in Pacific Societies, ed. Verena Keck, pp. 171206. Oxford: Berg.

Péter-Contesse, Eugénie. (1923-1951) personal correspondence. PMB 1011. Pacific Manuscripts Bureau, Canberra.

Rivera, Annamaria. 2005. La guerra dei simboli. Veli postcoloniali e retoriche sull'alterità. Bari: Dedalo.

Sam, Léonard Drïle. 1995. Dictionnaire Drehu-Français: (Lifou, NouvelleCalédonie): suivi d'un lexique français-drehu (pour débutants). Nouméa: Coédition du C.P.R.D.P. des Iles avec la participation du Vice-Rectorat.

Shineberg, Dorothy. 1999. The People Trade: Pacific Island Laborers and New Caledonia, 1865-1930. Honolulu: University of Hawai'i Press. 
Tcherkézoff, Serge. 2003. 'On cloth, gifts and nudity: Regarding some European misunderstandings during early encounters in Polynesia'. In Clothing the Pacific, ed. Chloë Colchester, pp. 51-75. Oxford: Berg.

Terra Madre Salone del Gusto website. 2008. Turin. Online: www. salonedelgusto.com (accessed 16 September 2016).

Thomas, Nicholas. 2005. 'Preface'. In The Art of Clothing: A Pacific Experience, ed. Susanne Küchler and Graeme Were, pp. ix-xi. London: UCL Press.

Tjibaou, Jean-Marie. 1996. La présence kanak. Edition établie et présentée par Alban Bensa et Eric Wittersheim. Paris: Odile Jacob.

Tjibaou, Jean-Marie and Philippe Missotte. 1978. Kanaké: The Melanesian Way. Papeete: Les éditions du pacifique.

Wapotro, Waimalo. 2010. 'Robe histoire’. Mwà Véé 69: 10-11.

Weiner, Annette B. 1989. 'Why cloth? Wealth, gender, and power in Oceania'. In Cloth and Human Experience, ed. Annette B. Weiner and Jane Schneider, pp. 33-72. Washington: Smithsonian Books.

Young Leslie, Heather E. and Ping-Ann Addo. 2007. 'Introduction'. in Hybrid Textiles: Pragmatic Creativity and Authentic Innovations in Pacific Cloth. Special issue of Pacific Arts 3-5: 12-21. 
This text is taken from Tides of Innovation in Oceania: Value, materiality and place, edited by Elisabetta Gnecchi-Ruscone and Anna Paini, published 2017 by ANU Press, The Australian National University,

Canberra, Australia. 